\title{
Difference in Increasing Mathematical Creative Thinking Ability and Discipline Learning Through Problem Based Learning and Matlab Assisted Think Pair Share
}

\author{
Hanifan Nursyah Fitri Siregar \\ Post Graduate Mathematics Education \\ State University of Medan \\ Medan, Indonesia \\ Corresponding email: hanifansiregar1992@gmail.com
}

\author{
Mulyono \\ Faculty of Mathematics Education \\ State University of Medan \\ Medan, Indonesia
}

\author{
Bornok Sinaga \\ Faculty of Mathematics Education \\ State University of Medan \\ Medan, Indonesia
}

\begin{abstract}
This paper is just a sample template for the prospective authors of IISTE Over the decades, the concepts of 1) A difference in the increase in mathematical creative thinking skills between students given a higher Problem Based Learning (PBL) model than students given Matlab Assisted Think Pair Share (TPS) models, (2) A difference discipline of learning mathematics between students who were given a Problem Based Learning (PBL) model higher than students given a Think Pair Share (TPS) model in Matlab Assisted, (3) A difference in the process of solving students' answers when solving mathematical creative thinking skills after obtaining a higher Problem Based Learning (PBL) model than students given Matlab Assisted Think Pair Share (TPS) models.
\end{abstract}

Keywords-Problem Based Learning (PBL), Think Pair Share (TPS), creative thinking skills, discipline of learning and matlab

\section{INTRODUCTION}

Education is very important and is a fundamental pillar for humans in facing world development. The same thing was expressed by [9] that the development of Science and Technology (Science and Technology) is currently very fast so that information from anywhere can be known immediately and the time and national boundaries are no longer different, as a result a period or era was born known as globalization.The importance of mathematics in the development of science and technology (science and technology) so mathematics must be taught at every level of education. According to [10] that mathematics must be taught by every unit of education starting from elementary school to college. Mathematics education as part of education has a role in people's lives because it is one of the factors that need to be considered for the development of science and
technology.(Suriyani, Hasratuddin, Asmin 2015) states that creativity in mathematics is more emphasized in the process, namely the process of creative thinking. Therefore, creativity in mathematics is more properly termed as mathematical creative thinking. However, the term creativity in mathematics or mathematical creative thinking is seen to have the same understanding, so that it can be used interchangeably. Of the 35 students in the class $95 \%$ students or 31 students answered with a single answer, while the rest answered in different ways and different techniques even though the answer was not correct. Students have not been able to provide problem solving solutions with different techniques and correct solutions

\section{THEORETICAL FRAMEWORK}

\section{A. Creative Thinking}

[5] states that creative thinking is thinking that leads to the acquisition of new insights, new approaches, new perspectives or new ways of understanding things. The ability to think creatively is the ability to generate ideas or new ways of producing a product. [13] states that the ability to think creatively as the ability to express answers and ideas that are considered the most appropriate and best in solving a problem and the idea is original or derived from his own thoughts even though it is a combination of several ideas that have been there before. Mathematical creative ability is a thought process to analyze arguments and bring ideas to each meaning to develop a logical mindset that must be developed by the teacher in learning. This is in accordance with what is the goal of learning mathematics, namely through learning mathematics students are expected to have the ability to think logically, analytically, systematically, critically, and creatively, and have 
the ability to cooperate. [16] states that the ability to think creatively in mathematics can use two approaches. The first approach is to pay attention to students' answers in solving problems whose cognitive processes are considered as creative thinking processes.

\section{B. Discipline Learning}

[11] states that discipline is an order in life that is in accordance with applicable rules or acts in accordance with rules that are agreed upon collectively or made by those concerned. [17] states that in the community environment discipline is meant by obeying the rules that have been made by the community. [8] states that discipline is compliance with regulations or subject to supervision or control. It can be understood that discipline is an order, that is obedience (obedience) to the rules of the code and so on. Being disciplined means obeying (obeying) order. [7] states that discipline is essentially a strict observance that is supported by awareness to carry out the duties and obligations as they should according to the rules or procedures that should apply in a certain circle. [15] states that children who are disciplined are children who can control themselves (self control). Selfcontrol can be known from several indicators, including: being able to control behavior and emotions, complying with applicable regulations, preventing yourself from inappropriate behavior, being patient, and focusing on doing tasks.

\section{Problem Based Learining}

The Problem Based Learning (PBL) model is an effective approach for teaching practicing high-level thinking processes. Where small groups together solve problems that have been agreed upon by students and teachers. When the teacher is applying the learning model, students will use a variety of skills, problem solving procedures, and creativity in solving these problems. [2] Problem Based Learning (PBL) model is based on constructivist theory, Problem Based Learning (PBL) is a learning approach where students work on authentic problems with a view to compiling their own knowledge, developing inquiry and higher level thinking skills, independence and trust. [13] states that the Problem Based Learning (PBL) model is supported by learning theory. For example, Jean Piaget's learning theory that supports Problem Based Learning (PBL), this is because new knowledge is not given to students in the form but the students build and develop their own knowledge from the results of interactions with their environment. In addition, learning theory that supports the Problem Based Learning (PBL) model is Vigotsky's social constructivism theory which believes that knowledge cannot be transferred from another person's mind to someone's mind but rather that the person must build his or her own knowledge through interaction with others.

\section{Think Pair Share}

[1] states that the Think pair share strategy (TPS) thinking in paired sharing is a type of cooperative learning designed to influence student interaction patterns. [12] states that in order to arouse students' motivation to learn, it is necessary to use attractive learning models and media, one of which is the Think Pair Share (TPS) type of cooperative learning model. This type of Think Pair Share (TPS) learning is a simple cooperative learning consisting of two members in one group who have different levels of ability.

[3] in his research stated that learning in pairs is expected to increase student activity because there are friends to think and exchange opinions, ask each other questions, and help each other to investigate. Meanwhile, to arouse the courage to express opinions can be developed by discussion in groups and develop mental socially is to establish relationships, feel the responsibility to obtain knowledge can be poured through sharing (sharing). [4] states that Think Pair Share (TPS) is learning that gives students the opportunity to work alone and cooperate with others. In this case, the teacher plays an important role in guiding students to discuss, so that a more lively, active, creative, effective and enjoyable learning atmosphere is created. This is similar with [6] states that the main purpose of cooperative learning is to maximize student learning to improve academic achievement and understanding both individually and in groups.

\section{RESEARCH QUESTION}

The following research questions were formulated to guide this study:

1. Is a difference in the increase in mathematical creative thinking skills between students given a higher Problem Based Learning (PBL) model than students given Matlab Assisted Think Pair Share (TPS) models?

2. Is a difference discipline of learning mathematics between students who were given a Problem Based Learning (PBL) model higher than students given a Think Pair Share (TPS) model in Matlab Assisted?

3. Is a difference in the process of solving students' answers when solving mathematical creative thinking skills after obtaining a higher Problem Based Learning (PBL) model than students given Matlab Assisted Think Pair Share (TPS) models?

\section{RESEARCH METHOD}

This type of research is quasi-experimental (quasiexperimental). The purpose of this study is to reveal the differences in the improvement of creative thinking abilities and the discipline of learning mathematics through the learning model Problem Based Learning (PBL) and Think Pair Share (TPS) in Eria Private High School assisted by matlab. This research was conducted by Eria Medan Private High School address at Jalan Sisingamangaraja IX No. 195. The research was carried out in the even semester of the 2018/2019 Academic Year, namely from April to May a total of 6 meetings, consisting of 1 pretest, in the Problem Based Learning (PBL) model and Think Pair Share (TPS), 3 the meeting was given a treatment model Problem Based Learning (PBL) and Think Pair Share (TPS), and 1 time giving a posttest in the class model Problem Based Learning (PBL) and Think Pair Share (TPS). 


\section{Data Analysis, Result, AND DisCussion}

Analysis of the difficulties of students' creative mathematical thinking processes is carried out by ANACOVA.

\section{A. Data Description and Data Analysis}

\section{$3.1 \quad$ Data Normality Test}

TABLE 1 TEST RESULTS NORMALITY OF CREATIVE THINKING ABILITY

\begin{tabular}{|c|c|c|c|c|}
\hline \multicolumn{2}{|c|}{ Learning } & $\mathbf{N}$ & $\mathbf{D}_{0}$ & $D_{\text {table }}$ \\
\hline \multirow{2}{*}{$\begin{array}{l}\text { Pre- } \\
\text { Test }\end{array}$} & PBL & 30 & 0,137 & 0,248 \\
\hline & TPS & 30 & 0,154 & 0,248 \\
\hline \multirow{2}{*}{$\begin{array}{l}\text { Post- } \\
\text { Test }\end{array}$} & PBL & 30 & 0,144 & 0,248 \\
\hline & TPS & 30 & 0,152 & 0,248 \\
\hline
\end{tabular}

TABLE 2 STUDENT DISCIPLINE NORMALITY TEST RESULTS

\begin{tabular}{||l|l||l||l||l||}
\hline \hline Questionnaire & Learning & N & D $_{\mathbf{0}}$ & D $_{\text {table }}$ \\
\hline \hline \multirow{2}{*}{ Statment I } & PBL & 30 & 0,116 & 0,248 \\
\cline { 2 - 5 } & PBL & 30 & 0,118 & 0,248 \\
\hline \multirow{2}{*}{ Statment II } & TPS & 30 & 0,152 & 0,248 \\
\cline { 2 - 5 } & TPS & 30 & 0,130 & 0,248 \\
\hline
\end{tabular}

\subsection{Data Homogeneity Test}

TABLE 3 HOMOGENEITY TEST RESULTS OF MATHEMATICAL CREATIVE THINKING ABILITY

\begin{tabular}{||l||l||l||l||l||}
\hline \hline & Class & Varians $\left.\mathbf{( s}^{\mathbf{2}}\right)$ & $\mathbf{F}_{\text {count }}$ & $\mathbf{F}_{\text {table }}$ \\
\hline \hline $\begin{array}{l}\text { Pre- } \\
\text { Test }\end{array}$ & Experiment I & 109,60 & 1.09 & \\
\cline { 1 - 1 } $\begin{array}{l}\text { Post- } \\
\text { Test }\end{array}$ & Experiment II & 101,1 & & \multirow{2}{*}{1,86} \\
\hline \hline
\end{tabular}

TABLE 4 HOMOGENEITY TEST RESULTS STUDENT LEARNING DISCIPLINE

\begin{tabular}{||l||l||l||l||l||}
\hline \hline Questionnaire & Class & $\begin{array}{l}\text { Varians } \\
\left.\mathbf{( s}^{\mathbf{2}}\right)\end{array}$ & $\mathbf{F}_{\text {count }}$ & $\mathbf{F}_{\text {table }}$ \\
\hline \hline \multirow{2}{*}{ Statement I } & Experiment I & 109,6 & \multirow{2}{*}{1,09} & \\
\cline { 2 - 4 } & Experiment II & 101,0 & \multirow{2}{*}{1,86} \\
\hline \multirow{2}{*}{ Statement II } & Experiment I & 123,2 & 1,84 & \\
\cline { 2 - 4 } & Experiment II & 227,2 & 1,84 & \\
\hline
\end{tabular}

\subsection{Determine the Regression Model}

Based on the test results of students' mathematical creative thinking abilities obtained regression equation for experimental class $\mathrm{I}$ is $\mathrm{Y}_{\mathrm{E}}=63.161+0.449 \mathrm{X}_{\mathrm{E}}$ and regression equation for experimental class II $\mathrm{Y}_{\mathrm{K}}=26.823+0.866 \mathrm{X}_{\mathrm{K}}$. Based on the results of student learning discipline obtained regression equation for the experimental class $\mathrm{I}$ is $\mathrm{Y}_{\mathrm{E}}=6.704$
$+1.164 \mathrm{X}_{\mathrm{E}}$ and the regression equation for experimental class II $\mathrm{Y}_{\mathrm{K}}=5.968+0.954 \mathrm{X}_{\mathrm{K}}$.

\subsection{Independent Test $X$ of $Y$}

TABLE 5. ANALYSIS OF VARIANCE FOR CAPABILITY INDEPENDENCE TESTS CREATIVE THINKING EXPERIMENT CLASS

\begin{tabular}{|c|c|c|c|c|}
\hline $\mathbf{A}$ & b & SSTO & SSR & SSE \\
\hline 63.161 & 0.449 & 3574.219 & 639.586 & 2934.632 \\
\hline MSR & MSE & Fh & Ft & \\
\hline 639.586 & 104.808 & 16.102 & 4.171 & \\
\hline
\end{tabular}

TABLE 6. ANALYSIS OF VARIANCE FOR CAPABILITY INDEPENDENCE TEST CREATIVE THINKING EXPERIMENT CLASS II

\begin{tabular}{|l|l|l|l|l|l|}
\hline A & b & \multicolumn{1}{|l|}{ SSTO } & SSR & SSE \\
\hline 26.823 & 0.866 & \multicolumn{2}{|c|}{6589.844} & 2194.731 & 4395.113 \\
\hline MSR & MSE & Fh & Ft & \\
\cline { 1 - 4 } 2194.731 & 156.968 & 13.982 & 4.171 & \\
\cline { 1 - 3 }
\end{tabular}

TABLE 7. INDEPENDENCE TEST RESULTS OF LEARNING INDEPENDENCE CLASS EXPERIMENT I

\begin{tabular}{|l|l|l|l|l|l|}
\hline A & b & \multicolumn{1}{l|}{ SSTO } & SSR & SSE \\
\hline 6.704 & 1.164 & 2064.667 & 1562.252 & 502.415 \\
\hline MSR & \multicolumn{1}{|l|}{ MSE } & F $^{*}$ & Ft & \multirow{2}{*}{} \\
\cline { 1 - 4 } 1562.252 & 17.943 & 87.066 & 4.171 & \\
\cline { 1 - 3 } & & &
\end{tabular}

TABLE 8. CLASSROOM STUDENT DISCIPLINE INDEPENDENCE TEST RESULTS EXPERIMENT II

\begin{tabular}{|l|l|l|l|l|}
\hline A & b & SSTO & SSR & SSE \\
\hline 5.968 & 0.954 & 1341.500 & 1216.994 & 124.506 \\
\hline MSR & MSE & F* & Ft & \multicolumn{1}{|c}{} \\
\cline { 1 - 4 } 1216.994 & 4.447 & 273.689 & 4.171 & \multicolumn{1}{|c}{} \\
\cline { 1 - 3 } & &
\end{tabular}

\subsection{Regression Model Linearity Test}

TABLE 9 LINEARITY TEST RESULTS THINKING REGRESSION MODEL CREATIVE IN EXPERIMENT CLASS I

\begin{tabular}{|c|c|c|c|c|}
\hline SSE & \multicolumn{2}{|c|}{ SSPE } & MSPE & SSLF \\
\hline 2934.632 & \multicolumn{2}{|c|}{2251.302} & 93.804 & 683.330 \\
\hline MSLF & Fh & $\mathbf{F t}$ & & \\
\hline 170.833 & 1.821 & & & \\
\hline
\end{tabular}

TABLE 10. LINEARITY TEST RESULTS OF THE REGRESSION MODEL OF CREATIVE THINKING ABILITY IN EXPERIMENT CLASS II

\begin{tabular}{|l|l|l|l|}
\hline SSE & SSPE & MSPE & SSLF \\
\hline 4395.113 & 3772.321 & 164.014 & 622.792 \\
\hline MSLF & Fh & Ft & \multicolumn{1}{|c}{} \\
\hline 124.558 & $\mathbf{0 . 7 5 9}$ & $\mathbf{2 . 6 4 0}$ & \multicolumn{1}{|c}{} \\
\cline { 1 - 2 } & &
\end{tabular}


TABLE 11 LINEARITY TEST RESULTS OF STUDENT LEARNING DISCIPLINE REGRESSION MODE IN EXPERIMENT CLASS I

\begin{tabular}{|l|l|l|l|}
\hline SSE & SSPE & MSPE & SSLF \\
\hline 502.415 & 323.167 & 29.662 & 176.137 \\
\hline MSLF & Fh & Ft & \multicolumn{1}{|l}{} \\
\hline 10.361 & $\mathbf{0 . 3 5 9}$ & $\mathbf{2 . 6 8 5}$ & \multicolumn{1}{|l}{} \\
\cline { 1 - 2 } & &
\end{tabular}

TABLE 12 LINEARITY TEST RESULTS OF STUDENT LEARNING DISCIPLINE REGRESSION MODEL IN EXPERIMENT CLASS II

\begin{tabular}{|l|l|l|l|}
\hline SSE & SSPE & MSPE & SSLF \\
\hline 124.506 & $\mathbf{7 6 . 0 0 0}$ & $\mathbf{6 . 3 3 3}$ & $\mathbf{4 8 . 5 0 6}$ \\
\hline MSLF & Fh & Ft & \multicolumn{1}{|c}{} \\
\hline $\mathbf{3 . 0 3 2}$ & $\mathbf{0 . 4 7 9}$ & $\mathbf{2 . 5 9 9}$ & \multicolumn{1}{|c}{} \\
\end{tabular}

\subsection{Similarity Test of Two Regression Model}

TABLE 13 SIMILARITY RESULTS OF TWO REGRESSION MODELS OF CREATIVE THINKING ABILITY

\begin{tabular}{|l|l|l|l|l|}
\hline A & b & \multicolumn{1}{l|}{ SSR (R) } & SSTO (R) \\
\hline 53.434 & \multicolumn{1}{|l|}{$\mathbf{0 . 4 7 3}$} & \multicolumn{1}{|l|}{1522.677} & 14125.000 \\
\hline SSE ( R) & SSE (F) & F* & Ft \\
\hline $\mathbf{1 2 6 0 2 . 3 2 3}$ & $\mathbf{7 3 2 9 . 7 4 5}$ & $\mathbf{7 . 0 0 8}$ & $\mathbf{4 . 0 0 7}$ \\
\hline
\end{tabular}

TABLE 14 THE SIMILARITIES OF THE TWO MODELS OF LEARNING DISCIPLINE REGRESSION

\begin{tabular}{|c|c|c|c|c|}
\hline A & b & SSR (R) & $\begin{array}{l}\text { SSTO } \\
(\mathbf{R})\end{array}$ & SSE ( R) \\
\hline-0.063 & 1.182 & 3551.815 & 6276.583 & \begin{tabular}{|l}
2724.768 \\
\end{tabular} \\
\hline SSE (F) & $\mathrm{F}^{*}$ & $\mathbf{F}(0.9$ & $5,1,58)$ & \\
\hline 626.921 & 75.605 & 4.007 & & \\
\hline
\end{tabular}

\subsection{Test of Alignment of Two Regression Models / Regression Coefficient of Homogeneity Test}

TABLE 15. ANALYSIS OF COVARIANCE CREATIVE THINKING ABILITY ALIGNMENT OF THE REGRESSION MODEL

\begin{tabular}{|c|c|c|c|c|}
\hline \multicolumn{5}{|c|}{ Combined Data Results } \\
\hline Class & $\sum x$ & $\sum r$ & $\sqrt{\sum_{y}}$ & SSI, (adi) \\
\hline $\begin{array}{l}\text { Experiment } \\
\text { I }\end{array}$ & 3178.39 & 3574.22 & 1425.78 & 2934.63 \\
\hline $\begin{array}{l}\text { Experiment } \\
\text { II }\end{array}$ & 3572.92 & 6589.84 & 2250.00 & 5172.93 \\
\hline SUM & 6751.30 & 10164.06 & 3675.78 & 8107.57 \\
\hline A & $\mathrm{B}$ & $\mathrm{Fh}$ & $\mathrm{Ft}$ & Ho \\
\hline 8107,57 & 8162,764 & 0,281 & 4,001 & $\begin{array}{l}\mathrm{Be} \\
\text { accepted }\end{array}$ \\
\hline
\end{tabular}

TABLE 16 COVARIANCE ANALYSIS OF STUDENT LEARNING DISCIPLINE FOR ALIGNMENT OF THE REGRESSION MODEL

\begin{tabular}{|l|l|l|l|l|}
\hline & SST $_{x}$ & SST $_{y}$ & SPT & $\begin{array}{l}\text { SST }_{x}(\mathbf{a d} \\
\mathbf{j})\end{array}$ \\
\hline PBL & 1152,800 & 2064,667 & 1342,000 & 502,41476 \\
\hline TPS & 1337,867 & 1341,500 & 1276,000 & 124,50578 \\
\hline SUM & 2490,667 & 3406,167 & 2618,000 & 626,92 \\
\hline A & B & F $^{*}$ & F table & Ho \\
\hline $\begin{array}{l}\text { 626,9 } \\
2\end{array}$ & 654,323 & 2,448 & 4,001 & $\begin{array}{l}\text { Be } \\
\text { accepted }\end{array}$ \\
\hline
\end{tabular}

\section{B. Discussion}

The results of the study showed that the ability to think creatively and discipline students' learning taught with Problem Based Learning (PBL) was better than the ability to think creatively and to discipline students who gained learning Think Pair Share (TPS). This is because Problem Based Learning (PBL) learning has advantages compared to Think Pair Share (TPS) learning. The application of the Problem Based Learning (PBL) model in mathematics learning requires students to learn to find concepts independently, practice their thinking skills, and analyze and manipulate information and it requires students to discipline learning in order to find concepts independently. By applying this model students can find and use diverse sources of information and ideas to increase understanding of an issue, topic or issue. Students are encouraged to learn largely through their own active involvement with concepts and principles.

Based on the principle of finding Problem Based Learning (PBL), students will learn to be actively involved in the experience and reflect on that experience. Students learn by building knowledge based on what they already know and through guidance in the learning process, students have many ways of learning and students learn through social interaction with others and students learn through instructions and experiences that are appropriate to their cognitive development. [2] also suggests that someone who is motivated will take action and behave in a certain way.

The use of Think Pair Share (TPS) learning for a very large number of classes, the teacher will have difficulty in guiding students who need more attention. Understanding the concepts in each pair will be different so that it will take additional time for the alignment of concepts by the teacher by showing the correct answer. More time is needed to present. The activities carried out by students in Think Pair Share (TPS) learning will make students not play an active role in learning. Think Pair Share (TPS) is suitable for increasing student participation in simple assignments, so that a student can also learn from other students and convey their ideas to be discussed before they are delivered to the class. But Think Pair Share (TPS) requires special attention in the use of classrooms. Training of all small group classes can take up valuable teaching time and a lot of time is wasted 


\section{CONCLUSION}

1. Improvement of students' mathematical creative thinking abilities who are given a Matlab-assisted Problem Based Learning (PBL) learning model is higher than the increase in mathematical creative thinking abilities of students who are given a Matlab-assisted Think Pair Share (TPS) learning model.

2. Improving student learning discipline given a Problem Based Learning (PBL) learning model supported by matlab is higher than increasing student learning discipline given a Think Pair Share (TPS) learning model assisted by matlab.

3. The process of solving students' answers to mathematical creative thinking tests and matlab-assisted Problem Based Learning (PBL) learning models shows better achievement of creative thinking abilities in solving given problems when compared to Think Pair Share (TPS) learning models assisted matlab

\section{REFERENCES}

[1] Aida, N. 2015. Pengaruh Model Think Pair Share Terhadap Prestasi Belajar Aqidah Akhlak Di Mi Muhammadiyah 25 Surabaya Kelas Iii,Iv Dan V. Tadarus: Jurnal Pendidikan Islam. Vol. 4, No. 2, 2015. Halama $1-14$

[2] Arends, R. (2008). Learning to Teach Belajar untuk Mengajar Edisi Ketujuh/Buku Dua. Terjemahan oleh Helly Prajitno Soetjipto dan Sri Mulyantini Soetjipto. 2008. Yokyakarta: Pustaka Belajar.

[3] Asmar, Mallow Dan Awuy. 2016. Penerapan Model Pembelajaran Kooperatif Tipe Think Pair Share (Tps) Untuk Meningkatkan Hasi Belajar Siswa Pada Materi Penarikan Kesimpulan Logika Matematika Di Kelas Xa Sma Karuna Dipa Palu. Aksioma Jurnal Pendidikan Matematika. Volume 5 Nomor 2, September 2016. Halaman 144-156

[4] Emda. 2014. Penerapan Model Pembelajaran Kooperatif Tipe TPS Di Sma Negeri 12 Banda Aceh. Lantanida Journal, Vol. 1 No. 1, 2014. Halaman 69-79

[5] Fitriarosah, N. 2016. Pengembangan Instrumen Berpikir Kreatif Matematis Untuk Siswa Smp, Prosiding Seminar Nasional Pendidikan Matematika 2016 Universitas Kanjuruhan Malang. Volume 1 Tahun 2016 - Issn 2528-259x

[6] Hasibuan. R, Sinaga Bornok. 2017. Perbedaan Kemampuan Pemecahan Masalah Matematika Menggunakan Model Pembelajaran Problem Based Learning Dan Discovery Learning Di Kelas VIII Smp Negeri 1 Percut Sei Tuan. Jurnal Inspiratif. Vol. 3. No. 1 April 2017. p-ISSN : 2442-8876, e-ISSN : 2528-0475. halaman 17-28

[7] Haryono, S. 2016. Pengaruh Kedisiplinan Siswa Dan Motivasi Belajar Terhadap Prestasi Belajar Siswa Pada Mata Pelajaran Ekonomi. Faktor Jurnal Ilmiah Kependidikan. Vol. 3 No. 3 November 2016, Hal 261 274

[8] Kazmi, R. 2016. Pengaruh Kedisiplinan Siswa Dan Motivasi Belajar Terhadap Prestasi Belajar Bahasa Indonesia (Survei Pada Sekolah Menengah Kejuruan Swasta Di Jakarta Timur). Jurnal SAP. Vol. 1 No. 1 Agustus 2016. Issn: 2527-967x. Halaman 27- 35

[9] Lubis Sri Delina. Surya, E dan Minarni, A. Peningkatan Kemampuan Pemecahan Masalah Matematika dan Kemandirian Siswa SMP Melalui Model Pembelajaran Berbasis Masalah. Jurnal Paradikma. Vol. 8. No. 3. Desember 2015. halaman 99

[10] Ningsih dan Nurrahmah, 2016, Pengaruh Kemandirian Belajar Dan Perhatian Orang Tua Terhadap Prestasi Belajar Matematika, Jurnal Formatif, 6(1): 73-84, 2016, ISSN: 2088-351x, halaman 73-84

[11] Rumia. 2015. Analisis Tingkat Kedisiplinan Peserta Didik Sebelum Dan Sesudah Prakerin Di Smk Negeri 3 Tarakan, Jurnal Kebijakan Dan Pengembangan Pendidikan. Volume 3. Nomor 1. Januari 2015. 117-125 Issn: 2337-7623; Eissn: 2337-7615. Halaman 117-125

[12] Sari, E, N. Wahyuni, E Dan Prihatin, J. 2014. Penerapan Model Pembelajaran Kooperatif Tipe Tps (Think Pair Share) Dengan Media Berbasis Website Untuk Meningkatkan Motivasi Dan Hasil Belajar Biologi (Siswa Kelas Xc Di Sman 2 Tanggul - Jember Tahun Pelajaran
2012/2013). Jurnal Pancaran. Vol. 3, No. 3. Agustus 2015. Hal 113 122

[13] Sunaryo, S. 2014. Model Pembelajaran Berbasis Masalah Untuk Meningkatkan Kemampuan Berpikir Kritis Dan Kreatif Matematik Siswa SMA Di Kota Tasikmalaya. Jurnal Pendidikan dan Keguruan. Vol. 1 No. 2. 2014. ISSN. 2356-3915. halaman 41- 51

[14] Suriyani, Hasratuddin, dan Asmin. 2015. Peningkatan Kemampuan Berfikir Kreatif dan Kemandirian Belajar Siswa MTs N 2 Medan Melalui Pembelajaran Matematika dengan Pendekatan Open-ended. Jurnal Tabularasa PPs Unimed. Vol 12 No 3. Desember 2015. halaman 224-234

[15] Sobri dan Moerdiyanto. 2014. Pengaruh Kedisiplinan Dan Kemandirian Belajar Terhadap Hasil Belajar Ekonomi Madrasah Aliyah Di Kecamatan Praya. Jurnal Harmoni Sosial. Volume 1 Nomor 1. 2014. Halaman 443-56

[16] Toruan, W, A. 2017, Medan. Tesis Pasca Sarjana Unimed Peningkatan Kemampuan Berfikir Krreatif Dan Disposisi Matematis Siswa Smp Negeri 2 Satu Atap Tebing Tinggi Melaluui Model Pembelajaran Kontekstual Berbantuan Flash.

[17] Wirantasa, U. 2017. Pengaruh Kedisiplinan Siswa Terhadap Prestasi Belajar Matematika. Jurnal Formatif . 7(1): 83-95, 2017. Issn: 2088351x. Halaman 83-95 